\title{
Interim Report on the Development of a Plastic Bonded Explosive
}

\author{
P. B. Archibald
}

\section{DISCLAIMER}

This report was prepared as an account of work sponsored by an agency of the United States Government. Neither the United States Government nor any agency thereof, nor any of their employees, makes any warranty, express or implied, or assumes any legal liability or responsibility for the accuracy, completeness, or usefulness of any information, apparatus, product, or process disclosed, or represents that its use would not infringe privately owned rights. Reference herein to any specific commercial product, process, or service by trade name, trademark, manufacturer, or otherwise does not necessarily constitute or imply its endorsement, recommendation, or favoring by the United States Government or any agency thereof. The views and opinions of authors expressed herein do not necessarily state or reflect those of the United States Government or any agency thereof.

PEOEMED

JAN 2919.97

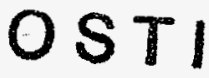

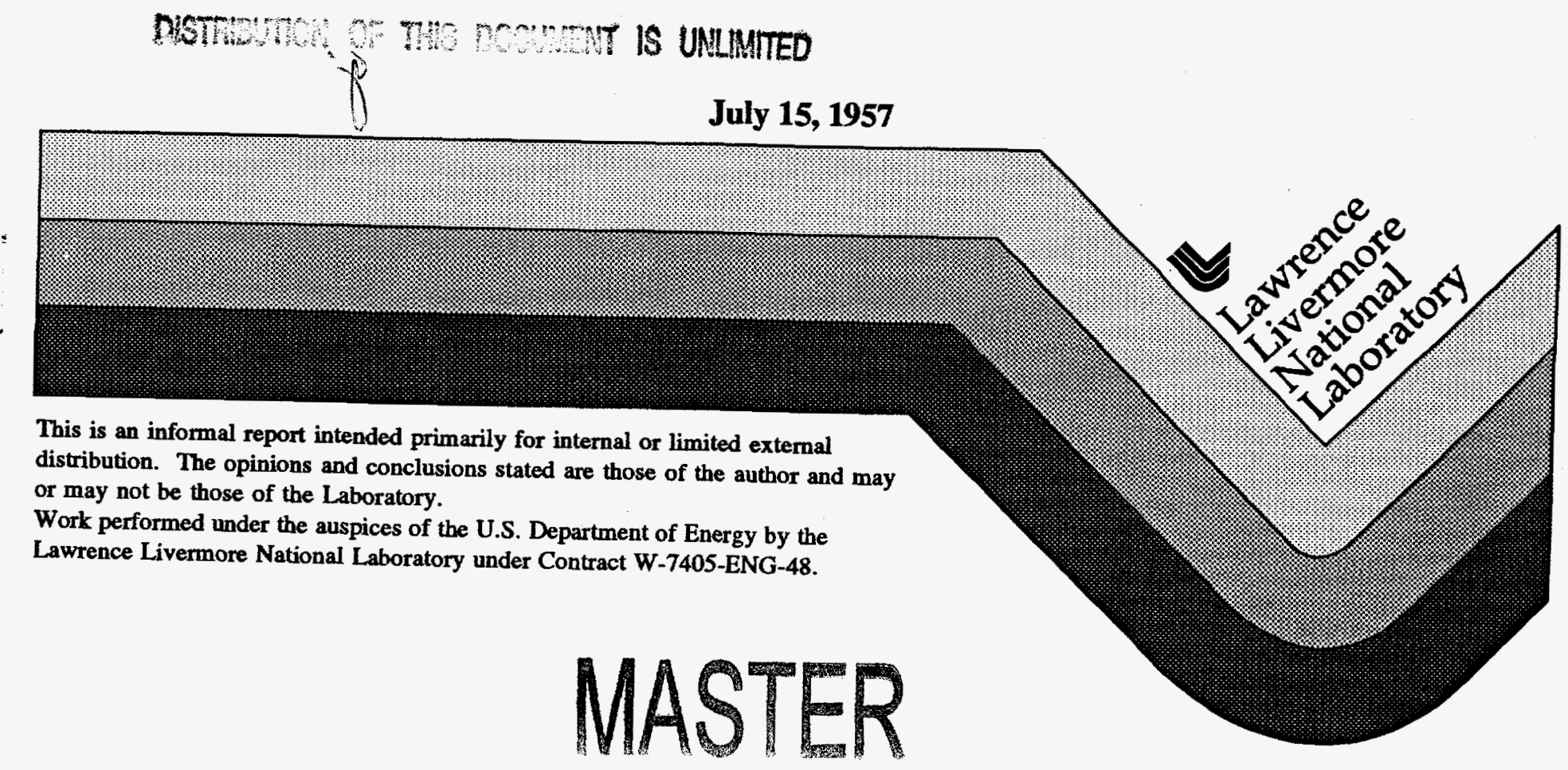




\section{DISCLAIMER}

Portions of this document may be illegible in electronic image products. Images are produced from the best available original document. 


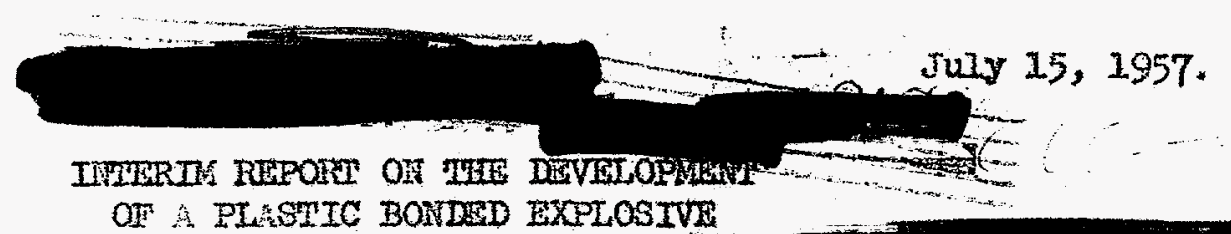

Paxt c. Archibald

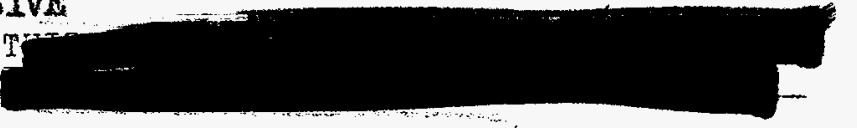

Purpose: The purpose of thi: vorix was to investigete the poscibilities of

producing a plestic bonded explosive hoving grester mechenteai strength then

that of presently existire pisetic bonded explosive.

Target values of azch tin explosive ure:

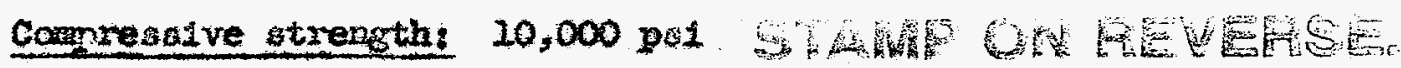

Sensitivity: Comparale to Comp. B or bettap

Demalty: th high as possible- houja ba $95 \%$ of theorettea gr bgtter

and asguring that one of the higher density explos wes as used.

Stability: Comparable co present plagtic botof explosives

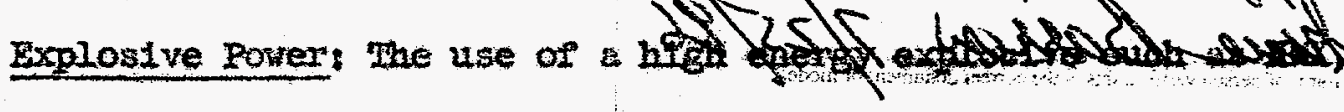

or Brata 1 s requared.

Formability: The material ahould be formable by acceptable promiction

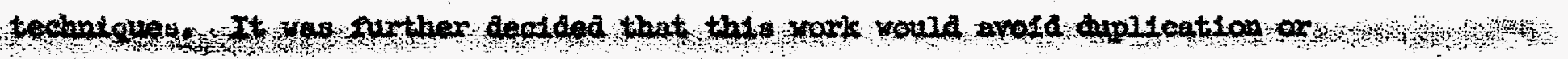

refinements of preeently knom plastic bonded explosives and that a radical approsch would be destrable.

Sethod: A prelininary consideration of the problem indicated that a suituble plastic bonded explosive might be produced by either of two approaches:

A: The use of en oxygen-rich explosive which fould permt the incorporation of a large smount (1.e. $20 \%$ of b naer)

B: The use of an axyen belanced explosive with mall atounts of binder which would not surt ract too mach for the explosive porex.

A survey of possible binders indicates that epoxy resins night be suitable.

These resins have outstiending atrength and whealons and can be polymorized at

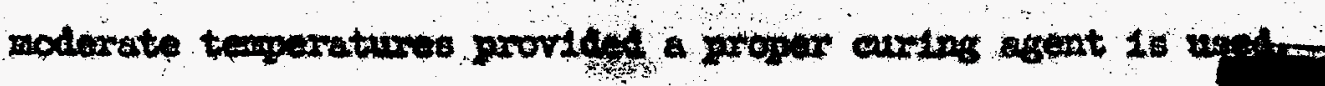




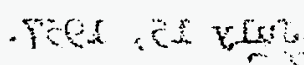

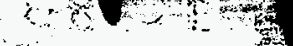

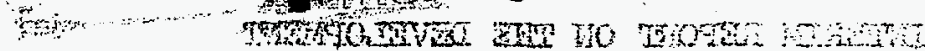

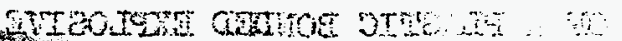

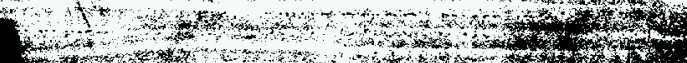

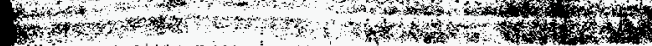

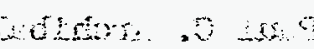

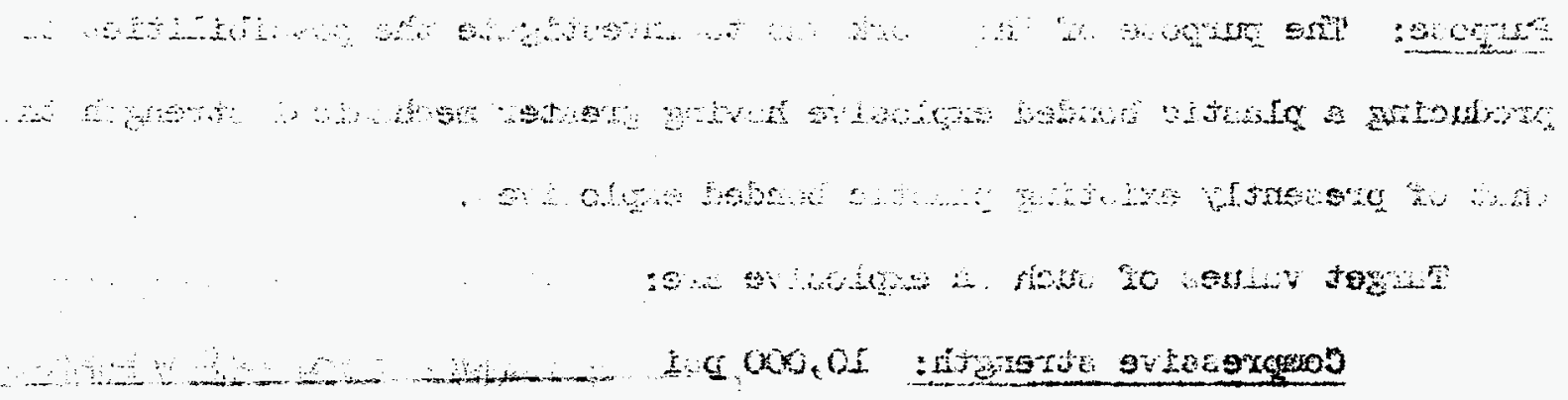

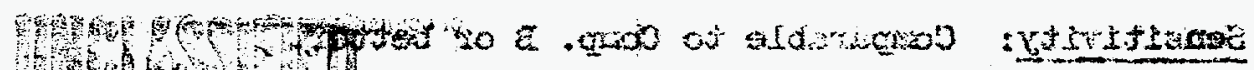

Whenters

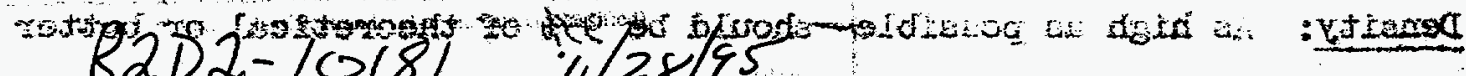

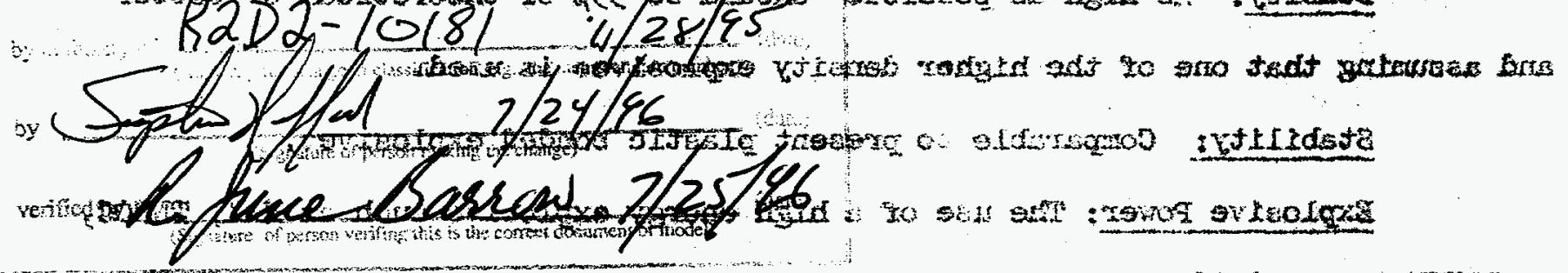

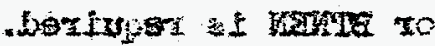

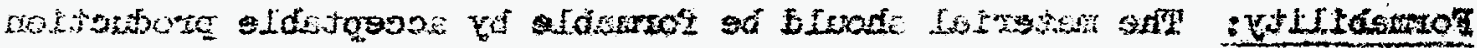

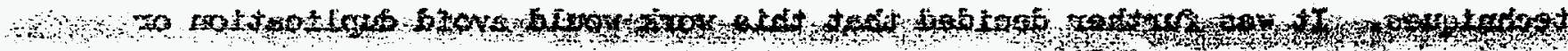

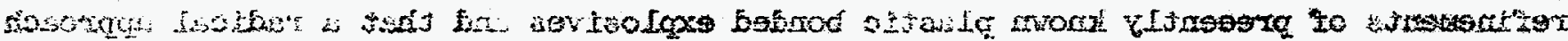

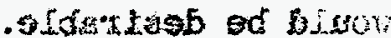

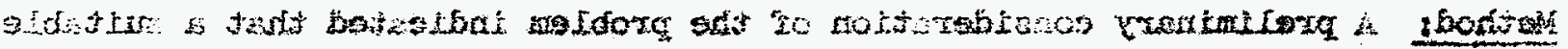

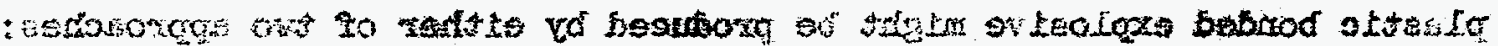

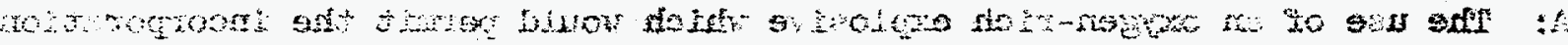

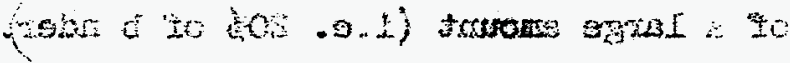

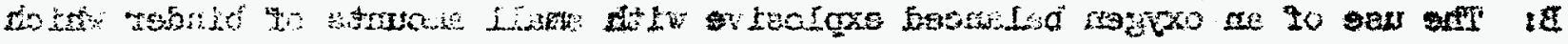

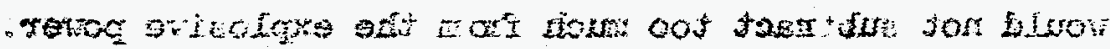

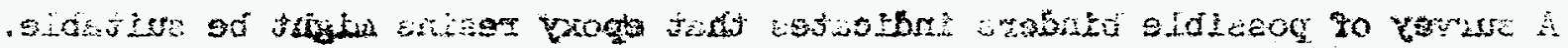

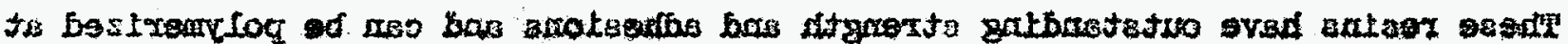

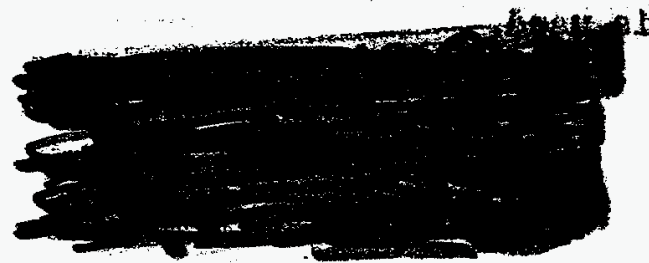

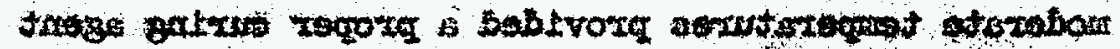


The posible use of such restns with the oxygen-rieh explosives vas abuaned When it ves found that the andne euring agents required for core reacted with Thoos and mint. It was alvo found that the oxygen-rich explosives rescted with other thermosetting plastios such as the polyesters and phenolics or their catalysts. Aprosah B Was then tried using IMX as the explosive and Epon 828 catalyzed With plperlaine as the binder, piperidine being selected as having a long pot Eeve and curing at $65-85^{\circ} \mathrm{C}$ with a low exothem. A cursory exanination indieated that mechantealiy strong pills could be mide with $3-7$ s of epoxy binder.

Reoulte: Using the techniques and materials described herein, a plastic bonded explostve was prepared having the following characteristics:

$$
\text { Target Value PBX(1) NoTs(2) PBA-6(3) }
$$

Compressive strength, psi: $\quad 10,000 \quad 3,500 \quad 8-10,000 \quad 10,000$

Sensft Ifty, $50 \%$ helght cat $>25$ 25 40 32

Density, gus/ce: 95\% theoretical

Vacume stabilfty: $(1.86 \mathrm{mal})(3)$

\subsection{2}

1.80

1.79

.3 ce $5-10$ ce

Fabrication: psi temp

(1) Velues of Los Alamos aitrocellulose bonded Mx

(2) Valuea of hons mylon bonded max

(3) Designation of mx-epoxy resin system (numeral 6 indicates $6 \%$ binder).

Preparetion of Test Specimens:

1. 䱦: Several methods or sample mixing vere inveatigated in in stempt to obtain the nost reproducible is well as the strongest spectmens.

Method A: This conasised of deposting the cutalyzed resin fron a solvent

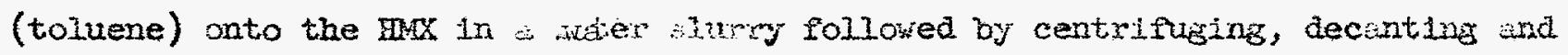
vacuum drying. This procedure involved many steps and was gite slow and hence mecures dry unsuited for experinental voris although it is the generel production method uged by Los Alamos. It was abundoned in fator: of method $B$. 
Method B: This nethod consisted of diluting the catalyzed restin

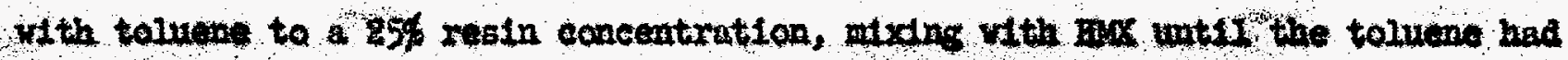
-vaporated. This procedure was faster than kethod A but Introhnced errors in weighing due to toluene evaporation and the problen of complete solvent renovi. Nethod C: This procedure, which finally adopted, wansisted of mixing the resin into the $\mathrm{mX}$ with a spatula followed by grinding in as mortar and screening. This wethod was the most satisfactory, at least for experimental rork.

2. Pressing: After the resin and Inx were mixed together and were in the foxw of a dightly damp porder, they were poured into the mold and pressed at 30,000 psi under vacuus for period of several minutes. The pills vere then pressed out of the die and cured st $80^{\circ} \mathrm{C}$ for 16 hours.

It us found that the looding of the die was a critical step in obtaintro

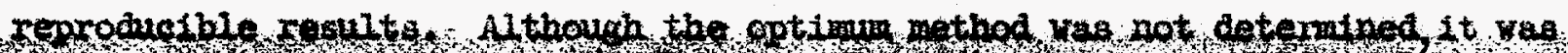

found that fairly good reproducibility could be obtatned by filling the die without packing and then tapping it gently to settle the naterial.

The use of a double acting press ins also inveatigated with good results. This conisisted of placing the die on a rubber cushion and allowing the botton ram to project through a hole in the mubber anto the steel base plate. This gave a $25 \%$ Increase in comprestve strength as well as a silght increase in dansity.

Curing the teat opecimens under pressure resulted in an additional increase in strength and density. A pill made using the double aeting ram and cured under preasure gave the po-lowing:

$$
\begin{aligned}
& \text { Den:toy: } \quad 1.22 \mathrm{~mm} / \mathrm{cc} \\
& \text { Compressive Strengin: } \quad 11,500 \mathrm{psi}
\end{aligned}
$$

Formilation: Due to the muy varibles in mixing and pessing of the pectinens, the development of the optimum formulation has been delayed. Wost of the techni ue derelopment work has been based on $24 \%$ bladex content bssed on $85 \%$ Epon 8.3 , 
10\% Thikol plasticizer and $5 \%$ ptperidine catalyst. Further inveatigation has Indleated Bmery 8 30-5 ( a polymerized fatty acld as a plasticizer ylelds specimens of higher ocmpressive trength). It aldo appacrs that $6 \%$ bluder content may be more desirable from a strength standpoint.

Other Variable Investigated:

Vacuum Presing va Atrospheric Presing : Specimens molded at atmospheric pressure did not show a isigniflcant decrease in strength or dansity. This may be related to the tendeney of Inon 828 under vacuum to foam for a period of time. Exposing the Hox-epoxy reain mixture to vacum of 2-3 hours before pressing did not hosever realt in a higher density or strength.

Effect of Pressure on Density: The effect of pressure on the density of the apecimen:

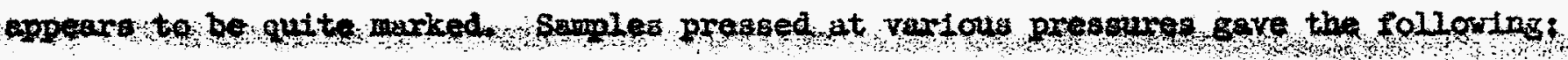

$\begin{array}{ll}20,000 \mathrm{psi} & 1.63 \\ 20,000 \mathrm{psi} & 1.71 \\ 30,000 \mathrm{psi} & 1.78 \\ 40,000 \mathrm{psi} & 1.81\end{array}$

(The wbove figures were obtained wth alngle scting ran pressins under vacuma)

Hot Pressing: Hesting the die before pressing gave an increase of $/ 02$ o $/ 02$ denitiy over cold pressing under the sane conditions otherwise.

Die Lubricant: An experiment iherein nolybdenum disulitde was rubbed into the die snd run did not result in bigher densty jpecinens.

Frfect of Fit of Die and Ren: $A$ ris wich was made on a Iathe by conventional wachive

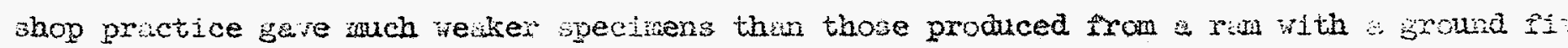
Epfect of post cure on strength: Post curing at $100^{\circ} \mathrm{C}$ for 3 hours did not yield ipecimens of higher compresive strength. Specimenis cured at $65^{\circ} \mathrm{C}$ for bixteen hours 9 phowed in anch lower strength than those cured it $80^{\circ} \mathrm{C}$. Distifution:
B. Rubin, copy $1 / 4 \mathrm{~A}$
a. Dorough, copy $2 / 4 \mathrm{~A}$

$* * * * * * * * * * * *$ 